\title{
Pocket-Picking to Armed Robbery to Prison: The Life and Criminological Analysis of Good Boy, Bad Boy and Wiser Man, Sal Ali
}

\author{
J Forbes Farmer ${ }^{1}, \mathrm{Sal} \mathrm{Ali}^{2} \&$ Jean Dawson ${ }^{1, *}$ \\ ${ }^{1}$ Department of Criminal Justice, Franklin Pierce University, 40 University Drive, Rindge, \\ NH 03461, USA \\ ${ }^{2}$ Prisoner in the Massachusetts, Department of Corrections, USA \\ *Corresponding author: Department of Criminal Justice, Franklin Pierce University, 40 \\ University Drive, Rindge, NH 03461, USA. E-mail: Dawsonj@Franklinpierce.edu
}

Received: January 7, 2021 Accepted: March 5, 2021 Published: March 23, 2021

doi:10.5296/jsr.v12i2.18161ＵRL: https://doi.org/10.5296/jsr.v12i2.18161

\begin{abstract}
This case study examines the self-reported life story of a prisoner who has spent much of his life in juvenile detention and adult prison. His criminal history began with pocket-picking, then breaking and entry, and then advanced to armed robbery. Social learning theory, self-control theory and rational choice theory are discussed and the inmate's reflections on them are offered in his words with illustrations from his experience.
\end{abstract}

Keywords: criminal theory, delinquency, case study, pocket-picking, armed robbery 


\section{Introduction}

In 1968 there were 262,840 robberies committed in the United States (FBI, 2018a). Salahuddin (Sal) Ali, the subject of the following case analysis, was ten years old at this time and was detained twice in a juvenile detention center for two of these robberies. In 1972, about 41,512 pocket-pickings were reported to the police (Federal Bureau of Investigation, 1976). Sal was fourteen at the time and was one of the offenders. In 1975 when Sal was seventeen, he committed a store robbery, one of 470,500 robberies in the United States that year (FBI, 2018a). In 2018, there were 26,085 pocket-pickings (FBI, 2018b) and 282,061 robberies (FBI, 2018a), but Sal was not one of the offenders, he was in prison where he remains today after two denials of parole.

As will be reported in his article, Sal learned how to commit crimes, first breaking and entering, then picking pockets (or shot playing as it was called by his friends), and then robbery. The more he committed these crimes, the better at it he became. He does not consider himself either an institutionalized youth or a career-criminal, although he knows people refer to him as such. He claims that "black people do not use such words" (S. Ali, personal communication, June 6, 2020).

\subsection{Theoretical and Research Basis}

Scholarly research has convincingly shown that as criminals gain more experience in their life of crime, the more they develop their skill set and their expertise (Nee, van Gelder, Otte, Vernham, \& Meenaghan, 2019; Grasmick, Tittle, Bursik, \& Arneklev, 1993). Reilly, Rickman and Witt (2012) and Willis (2006) noted this in their studies of armed robbers. Topalli, Jacques and Wright (2015) found this to be the case for carjackers. Felson (2002), Glaeser (2012) and Keohane (2011) referred to pocket-picking as a lost art of skill and finesse. Vieraitis, Copes, Powell and Pike (2015) confirmed the experience hypothesis as it applied to identity thieves. Holt, Bossler, and Seigfried-Spellar (2015) reported this for computer hackers.

The criminal theories that seem to best explain the acquisition of this expert knowledge are the micro-level, tabula rasa - based, symbolic interaction works of those who focused on the concept of social learning (Akers, 2000; Akers \& Sellers, 2012; Akers, Sellers, \& Jennings, 2017; Burgess \& Akers, 1966; Sutherland, 1939; Sutherland \& Cressey, 1950) and the concept of rational choice (Cornish \& Clarke, 1986; Herrnstein, 1990). Other theories also contribute significantly to an understanding of the development of the criminal mind and criminal behavior. Self-control theory (Burt, Simons, \& Simons, 2006; Gottfredson \& Hirschi, 1990), for example, is based on the hedonistic idea that people are basically selfish, and criminal behavior is a result of an absence of control mechanisms. What follows is a brief application of some of these theories to a case study of pocket-picking and armed robbery.

\section{Research Method}

Data for this qualitative research paper comes from a series of "slow mail" letter exchanges 
with an incarcerated felon serving time for armed robbery. He also has an extensive juvenile record of breaking and entering and pocket-picking (petty larceny).

Sal Ali, the source of the information in the presented case, was incarcerated in the Massachusetts Department of Corrections North Central Correctional Institution in Gardner, Massachusetts in 2003 when he and the first author met. Sal was a member of a group of self-selected prisoners who, under the supervision of a recreation officer, participated in Project Wakeup. This program, available to high school and college students, gave inmates an opportunity to tell their stories which included descriptions of crimes committed, descriptions of victims, stories about prison life, bad decisions the inmates had made, and advice to the program attendees. Sal was asked if he were interested in writing about his life of crime and participating in the writing of this case. It was explained to him that what he wrote would be edited and theoretical perspectives would be offered that could be considered and discussed through mail exchanges. Sal enthusiastically agreed, and this project proceeded. He wrote his story in the first person and much of that remains. However, some of it was changed to the third person (with Sal's approval) to facilitate its readability and theoretical reflections and analysis. Also, most of the names of people and places in Sal's story have been changed. Finally, due to his being transferred to a different prison and to the COVID-19 coronavirus pandemic of 2020, the authors and Sal have not been able to meet in person for some time.

Case studies, like the one that follows, are one of the most frequently used qualitative research methodologies in education, management, medicine, anthropology, clinical psychology, social work and sociology (Dul \& Hak, 2008; Johansson, 2003; Yin, 2003). Generally, case studies attempt to investigate and capture the complexities of a single case (Ebneyamini \& Moghadam, 2018; Stake 1995), and are able to be specifically designed to suit the case in question (Hyett, Kenny \& Dickson-Swift, 2014; Yazan, 2015). While there is no full consensus as to how case studies are designed and carried out, they usually are attempts to illuminate and explain decisions and how they were implemented (Schramm, 1971; Yin, 2003). They offer a holistic view and description of real-life events and bring out the viewpoint of the participant (Tellis, 1997) to offer a heuristic understanding of the phenomenon under study (Yazan, 2015).

\subsection{Methodological Limitation}

A common criticism of the case method, however, is that the results obtained might not be reliable or valid. Reliability refers to the replication of the method and obtaining the same or similar results so that generalizing to a larger population would be possible. This would be difficult to accomplish unless that case occurs at a specific location that could be visited at different times and from different angles, or the researcher was studying someone in a controlled environment. The validity issue is another matter. Are the presented research results truthful? Normally, this would be addressed through triangulation, collecting the data from at least three different sources. The case study presented here is based on only one source and must be taken at face validity. With that said, the potential value of the following case is that it can be used to provide context (Ebneyami \& Moghadam, 2018) in suggesting 
the applicability of several criminological theories. This is a common use of case method research (Dul \& Hak, 2008; Handfield \& Melnyk, 1998).

\section{Case Overview}

Salvatore Vaughn converted to Islam while in prison, took on the Muslim name of Salahuddin Ali, and goes by Sal. He has been incarcerated in the State of Massachusetts for well over two decades. He was sentenced to life for bank robbery. His extensive criminal history began in the early 1970s. He grew up in Boston during school segregation and experienced a segregated city where many young teenagers were involved in criminal activity as pick pockets, car thieves, or robbers. Sal was in and out of Juvenile Court from the age of thirteen to seventeen and was committed to the Department of Youth Services (DYS) on numerous occasions. He was discharged from DYS and then considered an adult. With crime a big part of his daily routine, Sal began to commit armed robberies. Drugs were also playing a role in his life, shaping his thinking and actions that were becoming more dangerous. He started taking risks and endangering his own life as well as those he would target to steal from and rob. The use of marijuana, pills, cocaine, heroin, and alcohol all numbed him to a point of having no fears in taking these risks. After his first adult prison sentence to Concord State Prison at age eighteen. Sal only became more determined to increase the crime that he had learned from older inmates who were doing time for major robberies. At age sixty-two, after 27 years in the prison system, Sal has stopped committing crimes. Sal has spent many years helping youth to avoid making bad decisions. What follows is his story.

\subsection{The Formative Years}

Sal's mother was born in Cape Cod, Massachusetts in 1928. She was a Cape Verdean whose parents, during the late 1800 s or early 1900s, came from the islands of Cape Verde, 385 miles off the coast of West Africa. She left Cape Cod at age nineteen and moved to San Francisco, California where after some time she met Sal's biological father who was stationed in the US Navy in San Diego. She had her own way of disciplining her children. She did not smoke or drink. Sal believes she finished the eighth grade. She knew how to manage the family. After age thirteen, the Department of Youth Services (DYS) became Sal's parents. The Massachusetts Correctional Institutions adopted him.

During the Korean war in the 1950s his father was on the USS aircraft carrier Wasp where he worked as a heavy equipment operator after being honorably discharged. His father was Native American "with Italian blood in him" (S. Ali, personal communication, June 28, 2020), and was raised in Washington, DC. "My Pops was a real smooth hip-cat" (S. Ali, personal communication, March 23, 2020). Sal remembers asking his mother, "Ma, what's dad's nationality, Indian?" His mother answered, "mo nigga than anything else" (S. Ali, personal communication, May 28, 2020). Sal's paternal grandmother was from Virginia. His grandparents on both sides were strict disciplinarians, very religious and hard-working farmers and construction workers. Sal was baptized as a Catholic.

Still in California, his sister was born first, then his brother Ray, then Sal in 1958, and his 
other brothers came after. They owned a house in Sharon Heights. In 1961, his parents broke up and his father returned to Washington, DC. Sal's mother, with all the children, did not have the finances to keep up the mortgage payments and lost the house. "My mom brought me up in a tough manner. She saw me at a young age developing into a complicated young man who would enter a dangerous criminal lifestyle. She warned me until it exhausted her. We were close all my life even up to her departure at age 88" (S. Ali, personal communication, May 28, 2020).

Sal remembers her parenting and warnings. "Oh, you sons of bitches think I'm coming home after standing on my feet all day at work to find dishes in the sink and a full trash can that no-one emptied. Get your ass moving now." "Sal, make your brothers lunch. Open that can of chopped meat [USDA food] and fry it." "Don't let me come home and find this house a mess or hear that you all were fighting." "If no one has their homework done, no one goes out. Your asses will be grounded." "I love you, but you don't want to listen. The white man will keep you until you're 21." "If the police come here for something you stole from the mall I'm going to tell them to lock your ass up. If you don't want to go to school, they have a place for you." (S. Ali, personal communication, August 18, 2020).

While Sal's mother was tough on him, he also remembers her as being warm and supportive. She sometimes got angry and shouted at him and might threaten to hurt him. She disciplined him on a regular basis, but sometimes later would not discipline him for the same thing. She helped him do things that were important to him and let him know she cared about him and loved him. He also believes she understood how he felt about things:

From 1966 to 1969 the Woodside Boys Club in Sharon Heights, California is where I learned to box and play pool, ping pong and pocket-billiards. I had blue ribbons in all categories from the age of nine to eleven. My older brother Ray (Peewee) had the same ribbons. The guy who ran the Boys Club had me fighting everyone in my age category. When he saw my fighting success, he brought in a heavier kid with height who may have been a couple of years older. He put me down with one punch. That put my juvenile fly weight aspirations in boxing to rest. Later, I boxed in Concord and Walpole state prisons. This is where my physical discipline came from. I still spar occasionally with a young man who wants to learn specific moves. All boxing is banned including speed bags, heavy bags, boxing gloves and hand wraps. HIV, Hep-C, and young gang members wanting to beef with rivals changed the boxing game in prison. With none of the equipment today, I had to use garden gloves, four to five on a hand. (S. Ali, personal communication, June 11, 2020)

Growing up in Sharon Heights, California, Sal Ali started his criminal behavior and spent time in juvenile detention. His first arrest came when he was ten years old and in the third grade at West Haven Elementary School. Using a Cub Scout pocketknife, he threatened two kids his own age in a school yard and got 75 cents that he split with his close cousin. They bought a soda and potato chips. Entering his house a few days after the heist, his mother said, "Sal, a detective was here. He will be here tomorrow morning to speak with you" (S. Ali, personal communication, March 23, 2020). She did not tell him that the detective was coming 
to pick him up. The next day, while his five other brothers went to school, the detective pulled up and took Sal to the Sharon Heights Police Station. There they took his mug shot and delivered him to Juvenile Hall in Hillcrest, California where he was held for 21 days before being released and taken home. A month later, Sal was arrested again for a $\$ 2$ robbery with a friend whose mother was the school-yard monitor at Belle Haven. He and his friend were held for two days at Hillcrest Detention and then set free.

Around this time, a friend of Sal's mother, showed up from Massachusetts. He was a master carpenter. He became a stepfather to Sal and his brothers. In 1969, he packed Sal, his brothers and Sal's mother into a station wagon and drove 3,000 miles across the country to Massachusetts. He had warned Sal on a few occasions that, "Massachusetts did not play. They would put your ass away for a long time if you did such and such" (S. Ali, personal communication, March 23, 2020). This man was like a real father to Sal and his brothers. They arrived first on Cape Cod in Falmouth, where all of Sal's mother's family members lived. They stopped at his maternal grandmother's house. Sal and his brothers had only heard about her. Sal's mother had not been back on her birth soil for a long time. So, in 1969 they settled here briefly with Sal and one brother at Sal's aunt's house and two brothers at another relative's house. They were quickly enrolled in public school (third or fourth grade), but only for a few months because it was close to school ending for the summer. Sal does not remember much about school. "Matter of fact, I don't remember learning a damn thing in the two months enrolled" (S. Ali, personal communication, March 23, 2020).

At that time, the concrete foundation for McDonalds had been poured, but no building had been started. Sal and his brother could stand on the cement and watch cars go by. They lived right next door. Behind where his aunt lived was a first-floor paint shop, and upstairs was Walter's Gun Shop. A path was behind these shops where they could cut through to go to school. Often, after school, Sal would walk up the stairs to the gun shop and talk with Walter. He was tall. Pistols, rifles, and shotguns lined the wall behind the counter. Walter and Sal became friends. Walter knew Sal lived right in front of this building. Sometimes Walter would ask Sal to answer the phone if he went downstairs to the paint shop. On a few occasions, he would let Sal wear a Smith and Wesson in a holster with bullets over his shoulder while hanging around the shop. Not one time did Sal ever remove the gun from the holster. Plus, it was too heavy.

All combined, the gun, holster and the bullets weighed more than I did. At age 11, in a gun shop wearing the whole gear, a gun in holster with bullets, I was feeling like I was top dog. No one entering Walter's Gun Shop would ever even think of a gun battle with me or Walter. (S. Ali, personal communication, March 23, 2020)

Walter had a bear trap as an alarm system. He would set it behind the door when closing. A cigar box behind the counter always had some loose change in it. Sal remembers that Walter allowed him to dip into it for a few quarters, nickels, and dimes; enough to buy a few candy bars for him and his brother.

Then Sal moved away to Sacred Heart's home in New Bedford, Massachusetts with his other five brothers. This orphanage was run by catholic nuns. Because Sal's mother did not have 
her own place just yet and the kids were scattered around, his mother decided to place the boys in Sacred Heart's surrounded by a brick wall and a heavy gate fence. Many kids were there, girls and boys. They were taught very well. They went to mass daily and on Sundays. Father Carlton ran the place with some real pretty nuns and a few old mean ones, too. They were very strict. They wore those black and white habits. Sal and his brothers spent six months there. There were all kinds of activities for them. The kids were well dressed and kept clean. The food was very good. School was required. This is where Sal's writing and reading skills picked up.

While this was taking place, Sal's mother was in Boston preparing an apartment in the Centre Crossing Housing Projects. By the time it came close to leaving Sacred Heart's home, Sal's had been entrusted by the nuns to take up the money collection every Sunday morning. The parishioners from around the area attended mass and threw dollar bills and coins in the basket connected to the stick Sal would extend for the people to drop the loot in.

"No Sir! Heck no! It never crossed my mind to dip into that basket to peel off a dollar, never mind a quarter like the cigar coin box at Walter's Gun Shop. There was no way I was going to steal from the church collection box surrounded by statues of the Lord Jesus, the Virgin Mary and all the paintings of saints and angels watching all my moves during mass" (S. Ali, personal communication, March 23, 2020). Even if the thought of taking without asking ever came across Sal's mind at that time, his beliefs then were that, "Jesus, Mary, the saints and the Holy Ghost would have come off the walls and kicked my butt all the way back to California nonstop" (S. Ali, personal communication, March 23, 2020). Sal missed his Holy Communion by one week. It was time to go.

Sal and his brothers left Sacred Heart's home and with their mother moved to Boston into the Centre Crossing Housing Projects. They could see South Boston from their apartment and could view the ocean for miles. The Harbor Point Shopping Mall sat in between South Boston and the Projects. Everything a family needed to obtain was in the mall. There was food, clothing, electronics, and one small record shop. You did not have to leave the area to buy anything. The families in Sal's building were Black, except for four white families. Everyone knew everyone. There were kids Sal's age and younger. While three of Sal's younger brothers enrolled in elementary school, Sal and two other brothers enrolled in the Bryer Middle School. Sal only completed the sixth grade. In the fifth grade he began to get disruptive. He was not paying attention and began to talk when the teacher was at the chalk board. He was getting the attention of a few cute girls and was showing off. Getting called to the principal's office was becoming a problem for Sal. The assistant principal would punish Sal by having him sit in his office during the lunch period.

On the way to school every day, Sal would stop at the Project store called the "Beehive" to buy a fifty-cent bologna and cheese sandwich, potato chips, a cup cake, and a soda. To make some money, Sal began loading groceries in cars in front of the big mall. He and other Project kids would often earn up to ten dollars on the weekends. Cigarettes in the machine cost forty-five cents a pack.

Sal's school suspensions became a major issue for his mother and stepfather. The bottom line 
was that Sal could not wait to get out of school or to get suspended. He did not like any of his teachers. He was sure the teachers predicted some bad time ahead for him. Sal's step-"Pops" and mom broke up in early 1971. They had been in Massachusetts for two years. Boston was very segregated and racist. There were only a few black Boston policemen. When Sal was suspended with time on his hands and with his mother away at work and his stepfather separated, it was time for Sal to learn more techniques on how to steal money. He met a kid who was one year older in the mall on a Sunday evening riding a minibike with $\$ 300$ in his shirt pocket. All kids wanted a minibike. Sal asked himself if he should snatch the roll of money from the kid's pocket and run. He decided against it. Instead, he and the kid became good friends. This other boy who was 14 years old was a very clever and skillful juvenile thief. He did not go to school and had been put out. His mother and father were heavy drinkers. There were other kids in his family as was the case with other families in the Projects.

Tired of dealing with Sal and his older brother, the Bryer School kicked them out and sent them to the Henson Disciplinary School in the middle of the middle class section of Brookline. The Brookline police would be waiting at the Coolidge Corner in a police car for the Transit Trolley cars to pull up and let the black kids out. The school was only a few hundred feet from the trolly car stop. Even plain-clothes Transit police would ride the trolleys hoping to catch one or more of the Henson School pickpockets [shot players] going into a purse or someone's pocket.

"In the black section of Boston, Roxbury, some parts of Dorchester and Mattapan or the South End, there were always small groups of skilled thieves in various criminal endeavors" (S. Ali, personal communication, May 28, 2020). There were probably over 100 students at the school, all black, who had been put out of the Boston public school system. This was around April of 1971 and just before Henson School would close. Sal met many kids there, some would later end up in juvenile detention in Roslindale, Massachusetts in the custody of the Department of Youth Services and would be in and out of court until they reached the age when they would be considered an adult under Massachusetts state law. Years later many kids would end up in state prisons.

\subsection{The First Serious Encounter with the Law}

Irish cops from the District 11 Police Station patrolled the Centre Crossing housing Projects. There was one way in the Projects and one way out unless you had a boat. Sal did not know anyone who had one.

So, these cops would wait around the Project hallways to snatch whoever they had a warrant for which was usually older people. There were no gangs or crack dealers at that time. All drug dealers were older. Heroin, pills, and weed were the only drugs on the street at that time. One day me and my older brother, Peewee, were on the basketball court behind the apartments where we lived. Here come all three detectives in a regular patrol car driving right onto the basketball court. Obrese steps out first and says, "you come over here." I said, "for what?" All three detectives put me and Peewee in the car and took us to District 11 Police Station. The cops said we robbed a 
woman with a dog. Well, that was some real dog-shit lie. This old bag was an alcoholic, she lived across from our building. She was always drunk with her mutt on a leash. The dog would bark at anyone while she walked with him. The morning while we were on the court, she passed by us with her mutt. I remember possibly triggering the dog by throwing an empty can towards him. Then the woman let loose. "You no good niggas, I'll call the cops." (S. Ali, personal communication, March 23, 2020)

Half an hour after that the cops arrived. She told the police the boys robbed her. Sal's stepfather had already broken up with Sal's mother. She called him and told him what happened. They came to the police station to pick up the boys. This was Sal's first arrest in Massachusetts. It was three days away from his thirteenth birthday.

His stepfather got an old Jewish lawyer who was well known in Boston for getting pimps and prostitutes off the hook. For six months Sal and his brother were in and out of juvenile court. At the final hearing, the lawyer had the woman telling the truth one minute and lying the next minute. She finally admitted that she told the cops a lie because one of the boys had thrown a rock at the dog. The judge tossed out the case. The woman killed herself a year later. They say she was drunk and had cut her wrists and bled to death over the death of her husband. Sal speculated that is why she drank so much. Sal never saw her with anyone, just the dog that would always bark at someone.

God rest her soul. If it were possible, I would sit with her and apologize then hug her. And if Duke were not barking, I would have bought a dog biscuit for him. The dog had white and black spots so he could not have been a racist dog, though he may have been barking some racist shit at us, too. (S. Ali, personal communication, March 23, 2020)

From that time on, the Irish detectives were on Sal's case. A few months later all three cops charged Sal with breaking into one of the biggest stores and charged him with stealing items taken by other thieves. Whatever security people had on their stolen or missing items list, they claimed that Sal stole it during the break-in. Along with that charge was a stolen vehicle charge and a runaway charge. Sal's mother told the police he ran away.

That was the truth. She heard about us breaking into the store. I had $\$ 75$ in coins when they arrested me inside the Beehive store waiting for a cheeseburger. I was riding around the projects all night and did not want to go home. With all those coins I had and the ass whipping I would have received from my mother; the coins would have been hitting the floor and my brothers would have been scooping them up while I would have been praying for Jesus and Mary and all the saints from Sacred Heart's Home to rescue me from the fire I was receiving from my mother. (S. Ali, Personal communication, March 23, 2020)

At juvenile court the next morning the charges were read, and Sal's mother told the judge to lock him up because he would not listen to her and had been put out of school. Sal was so hurt to hear his mother tell the judge to lock him up that he often wondered if she told that 
detective the same thing back in California back in 1968 for stealing the 75 cents from the kid in the school yard.

Nonetheless, the court officers brought Sal down to the Dorchester Courthouse basement holding cells to await transfer to the juvenile detention lockup called the Youth Service Board. "Man, I cried very quietly so the men in the next cell could not hear me. Well, I had been warned and there was no time to be a punk" (Ali, Personal communication, May 28, 2020). Sal was on his way just two or two and a half miles to the lockup joint. Sal's life would be different. This three-story brick building with a barbed wired fence surrounding the yard for the juvenile prisoners was nothing compared to Juvenile Hall in Hillcrest, California where he was held on two occasions in 1968. All the males were on the second floor with kids his age, 13-16, while the other side had older youth. Some of them looked to Sal that they were in their late teens or early twenties. There were a few kids Sal knew on both sides. Some were from the disciplinary school in Brookline where the shot players [pick pockets] went. Sal was placed in a cell with Little Steve who was 12 years old. This kid looked like his brothers.

A few days later, Little Steve's mother and Sal's mother met on the first floor where the administration office was. The mothers had two plates of food for them waiting in the cafeteria where visits met. Sal and Little Steve were both there for two weeks. They were released and Sal now had new friends from Dorchester and Roxbury. Little Steve who was in the cell with Sal in juvenile detention was shot in the head by a store owner in 1972. Older kids with Steve walked into the store together. The owner claimed that Little Steve at thirteen years of age pulled a gun on him and he thought the gun was real. It was a toy gun.

Sal's old Centre Crossing Mall life and being chased by those three Irish detectives came to a halt. Sal had a few new buddies who picked pockets in downtown Boston and on the transit line of trains and trolly cars. From time to time Sal was in and out of juvenile court for shot playing. His mother moved out of the Projects. Sal's skinny buddy started stealing cars. Sal often wondered why he left the old crimes of breaking into stores and shot playing to stealing cars. For him, that seemed ass-backwards. Maybe the risk was less dangerous and riding a stolen car took him further than the minibike he rode when Sal and his buddy first met in the mall. At this point, when Sal was thirteen, he started smoking weed, had a couple of girlfriends and was on the constant move, living the young life of a thief.

\subsection{Turning Point}

After numerous arrests over a four-year period, Sal turned seventeen. He was now an adult and could kiss the juvenile court goodbye. Armed robbery with fake and real weapons stepped into play. There was no more dipping into pockets and purses for a few dollars. Sal's arrest for a store robbery at age seventeen landed him in the Concord, Massachusetts state prison. Who was there? Some of the other teens from the Henson School and from juvenile lockup at the Youth Service Board in Roslindale who Sal knew from running in and out of there from the age thirteen to seventeen. It was time for Sal to pick up on bigger things. Sal, and others like him who were growing up in custody, did not consider getting out to be good young men and pay taxes. "We planned to further rob and steal from those who had money. 
In my heart I never wanted to live this way of being a thief" (S. Ali, Personal communication, March 23, 2020). This was the only lifestyle he knew. No one took care of him but himself. "Food, clothes and, money. If I had better, I would have lived better" (S. Ali, Personal communication, March 23, 2020).

Sal had other brothers now at home living with his mother. Sal wanted to live alone. He had matured and felt 10 years older than he was. Once released after doing 13 months on a reformatory sentence it was time for Sal to put money back in his pocket. He worked briefly at a car seat cover company packing boxes, but he became impatient making only a minimum wage. He wanted more money and the only way to do that was to go back to what he knew best.

\section{Criminal Theories and Offending}

\subsection{Social Learning Theory}

Why do people commit crimes? The social learning theorists of crime (Akers, 2000; Akers \& Sellers, 2012; Akers, Sellers, \& Jennings, 2017: Burgess \& Akers, 1966; Sutherland, 1939; Sutherland \& Cressey, 1950) focus on the idea that people are born with a blank slate, tabula rasa, and that criminal motivation and behavior is learned. They believe that criminals learn to commit crimes in the same way as other people learn to conform. Social learning theory is based on the early twentieth century work of theorists at the University of Chicago who were exploring the connection between communication, action and meaning (Triplett, 2015) and continues to be a dominant and well tested theory today (Jones, 2017; Akers, Sellers, \& Jennings, 2017).

Sutherland, the first criminologist to develop this theory, believed that "A person becomes delinquent because of an excess of definitions favorable to violation of law over definitions unfavorable to violation of law" (Sutherland, 1939. p. 78). The definitions, attitudes, beliefs, and behavioral styles come from the interaction with, and influence of, peers and significant others. Thus, the culture of a person's home, school and neighborhood is important. Sutherland based his theory, called Differential Association, on the classical conditioning principles of psychology. Akers and Sellers (2012) claimed that criminal values, definitions, and techniques are learned through the methods of punishment and reinforcement used by peers and family.

Sal Ali agreed that all of Sutherland's (1939) nine principles listed and discussed in Differential Association are valid and can be related and attributed to anyone who is learning the criminal mind and behavior. The following reflections from his life story provide evidence of how Sal learned criminal motivations and techniques and support the validity of social learning theory.

\subsubsection{Picking Pockets and Purses and Breaking and Entering.}

While Sal's mother was at work, Sal was out of school. Sal wanted money to impress his friends and to buy items that he wanted; he knew asking his mother for any money would be 
futile. He started learning some criminal techniques.

It was from a quick, fragile, and very skinny kid that my friends and I learned various methods of "shot play" (picking pockets and purses). My two smallest friends were very skillful. We had to give them cover or block with our height whenever there was a "shot" (victim pocketbook, wallet) that was too low for the others to pick. Various shots were called a "deuce" (double strap pocketbook), "ace" (single strap) or a "flip" (cover-flap). To stick someone, you had to step in front of the victim, drop a few coins to stall them, giving me time (seconds) to pick their pocketbook or wallet out of their pocket, right side or left side. You had to use a soft touch and speed. Your fingers, if long, gave you an advantage to go deep. Just the use of two fingers. I could feel a wallet and could differentiate a wallet from other junk. If I could see a small envelope like a yellow or brown small bank envelope, I would remove that over a wallet. Sometimes a diamond ring or expensive watch would be in it. Whatever we got, we split. It could be $\$ 20, \$ 30$ or $\$ 100$. We had to split it. Sometimes we had good days. Other days could be slow with no heavy traffic on the bus, subway trains or trolly cars.

I cut my inside coat pockets to conceal my hands or use a newspaper so no one could see my hands in action. I had to unlock, then feel around quickly. Using stealth, speed and concealment was the method. Quickness and smoothness without letting the person feel your fingers in their pocket or purse. Sometimes people panicked and would yell "someone stole my wallet" with you standing right there with the wallet under your armpit or wrapped up in the folded newspaper under your armpit or in your coat pocket with the slit. What a position to be in trapped on the subway train or public bus that pulled off, door shut with the feeling that one of the undercover transit police would walk over to you and bust you with the wallet.

The last time I put my fingers in a pocket I came out with a plastic cover bank book and a small note pad thinking it was a wallet. The victim didn't know it and stepped on the bus. The door opened and I spun around. In my face were two transit police who grabbed me, took the bank book, and note pad out of my coat pocket and cuffed me. I must have been 16. I was charged in juvenile court for larceny. A bank book with the lady's name and the note pad. Not even a dollar. I was finished with shot playing. Only two of the five kids in my crew are still living, the oldest and me. The younger three all died over the years from drug related illnesses. Me and the oldest of the crew were the only ones to leave shot playing alone and started armed robbery crimes. 1972 to early 1974 was a period when we stopped running around as a crew. (S. Ali, personal communication, May 28, 2020)

During his childhood, Sal felt the relative deprivation of his family's economic status. This deprivation was often his motivation for his criminal behavior; he wanted things that his mother could not possibly afford (S. Ali, personal communication, October 4, 2020). During his adolescence, he also liked being able to have a roll of money to show off to his peers and 
girlfriends. Sal enjoyed hanging out with the skinny kid who did not drink or do drugs. They spent their time together improving their criminal pursuits:

The same skinny kid taught me how to break into shopping malls on Sunday nights when everything was closed. The ABC Security Company would respond to the alarm in their red security cars with a green flickering light at the top of their car. By the time they reached the shopping mall we were back inside the Projects with stolen TVs, jewelry, music equipment, $\$ 40$ or $\$ 50$ in coins from cigarette machines, BB guns, some clothes, cameras and other stuff. There was no need to conceal our identity, face, or fingerprints. There was an apartment in the Centre Crossing Projects where Mrs. Stewart sold "hand me down" clothes. For 50 cents I bought a used trench coat to conceal a utility belt that had a large screwdriver, mini crowbar, hack saw blade and a flashlight. These tools were my responsibility. We used them to break into the stores in the Harbor Point Shopping Mall. At that age of 13, I had no real job and to walk through the Projects with these tools just did not look right.

As time moved on, I learned more from the skinny kid. What really impressed me was how he could kick the back door of one of those stores which had a square box alarm system. Two hard kicks and the rear door would open. The box alarm was loud, and he would use the large screwdriver to pop the top part of the door alarm box and snatch the large square battery out. He would then run over to the cigarette machine that had a key lock at the top. He would use the same method around the top of the edge and pop right through the ledge and the whole front cover of the cigarette machine would fall. At the right corner of the machine was a metal box where all the coins would fall. In the meantime, we were scrambling in different departments grabbing electronics.

On a few occasions, we ran across the mall rear parking lot with color TVs on a stand while tailing behind each other with other stolen items. The store floor alarm also went off once our feet touched the inside of the store. It took six minutes for the ADT security cars to show up. One of us would see the car coming around a bend with the green flickering light on and someone would yell out, "ABC." When they got to the door that was open, we could see them from inside the Projects. Whatever we had we sold after splitting up the coins from the cigarette machine. (S. Ali, personal communication, May 28, 2020)

\subsubsection{Bank Robbery}

Sal believes that after growing out of the petty criminal mindset, going to prison at age eighteen and blending in with older minds, there was no need to rob or steal money that would only last for 24 hours. He admired the stick-up men he was around "who could enter white areas with high velocity weapons and commit a heist" (S. Ali, personal communication, October 4, 2020). He believed these guys showed great courage given the likelihood of being killed by the police during the commission of this type of crime. His mind set was on 
planning to get what he wanted, make a getaway without physically hurting anyone or being killed himself during the commission of a crime or during a car chase.

It took smaller coordinated and uncoordinated robberies to build up for a bigger one. You learned how to handle the people and not cause a big panic that would alert the police or someone who might be passing by. The concealing of the face and hands so as not to be identified was a very important process. Any panic caused by yelling or screaming could cause someone to have a heart attack, especially with a weapon pointed at them real or fake, but what they perceived to be life threatening if they did not comply. Alarms are dangerous death triggers. To flick a button in a place being held up can cause death. Timing to get in, take control, get the money, and get out was the objective. Listening was another factor. Signs from moving birds that knew the situation was key. A method learned in prison.

Robbing banks or places of business by me alone, or with help from someone to make sure my path was clear to get from point A to point B, came from years of developing criminal behavior growing up learning to steal in the streets. No matter what joints I robbed, or the methods used, there was never enough time to get it all. The major money is secured and locked down. Soon as I entered, silent alarms would go off that would activate police in a radius of miles that would be looking for the description of the robber and what he fled in. On the ground and from the sky, police would be scanning like dogs at a racetrack to catch the rabbit. The studying of ants and the holes they drill in the earth under small grass leaves to give them shade from the sun was another method to use from being identified from the sky by police. (S. Ali, personal communication, May 28, 2020)

Sal continued his criminal behavior with more risky dangerous robberies, drug use and coming close to death or possible shootouts with police. He was arrested again and received another conviction to state prison for a longer term. Now into Sal's twenties, there was another release, another arrest for bank robbery, then after ten years another bank robbery, and finally a trial with a life sentence. "Oh, not only did I see the life sentence coming, the birds in the trees saw it coming" (S. Ali, personal communication, March 23, 2020).

\subsection{Self-Control Theory}

Self-Control Theory is grounded in the classical idea that people at birth are hedonistic. It was first proposed by Hirschi (1969) who concentrated on the significance of social bonds (attachment, commitment, involvement, and belief) that youth develop with teachers, parents, and peers. If these bonds are made with conformist people, then the bonds serve as deterrents to criminal behavior. When these bonds are weak or with nonconformist people, then there is little preventing the pursuit of selfish, self-centered pleasure through illegal means.

Sal did not have a steady father figure for most of his life, but he had several father figures who often gave him good advice. Some of these men were war veterans and veterans of the harsh ghetto life. "Some were heavy drinkers, a couple of them drug users who came out of the dope shooting heroin era" (S. Ali, personal communication, August 18, 2020). Sal would 
encounter these men outside dangerous bars where they hung out. They would ask Sal, "Hey, young blood, whatcha up to? How's your family? You staying out of trouble?" One of these men, "always pushed me in the right direction to get things right. He would bring me around friends of his who he had grown up with. People who finished college and had good jobs. His example on how to conduct oneself was clear. His positive impact on me was to get an education. Years later this man ended up in state prison" (S. Ali, personal communication, August 18, 2020).

Gottfredson and Hirschi (1990) expanded on this notion and proposed a theory of low self-control. If child rearing and socialization are ineffective in creating self-control, then children will follow their natural predatory instincts, become thrill seekers, and use crime as a tool to receive pleasure.

This theory has most recently been advanced by Burt (2020), Burt and Simons (2013), Burt, Sweeten and Simons (2014), and Forrest, Hay, Widdows and Rocque (2019) who argue that not everyone is equally motivated to commit crimes. They believe there are independent influences and sensations that create individual differences in peoples' personalities. In general, however, self-control theory explains that "crime and delinquency would not occur if people were controlled either internally (conscience or self-control) or externally (fear of punishment or positive punishment for social involvement)" (Farmer \& Dawson, 2017, p. 5). Sal, the subject of this case study, reflected on this popular theory.

When you have a people that are living in a society with class separation, isolation, restricted to areas where crime is a way of life when drug dealing is out in the open, killing, police in and out of the area, prostitution, armed gangs, congested housing, projects or apartment buildings, it takes self-control not to become a thief or any other type of criminal. It depends on the status of one's family and where they live. In poor black and Hispanic regions, people are born into this setting.

Some will not dare walk into the traps of crime or drug use because they learn at young ages the negative outcome even when they know their educational future with a job or a company will not accept you with a criminal history even for petty crimes as a youth. Another group living under the same condition in a home with multiple siblings, single parent on welfare with no sight of a future due to the class separation, isolation and restricted to the ghetto area exposed to police shootings, arrests, trial and conviction, will say "fuck the law" and the consequences I need to be taken care of now. My family is in need and if I'm arrested, I'll deal with whatever follows behind it. People with clear insight that observe racism and class separation also living under economic oppression watching criminal activity, go on to finish school, earn degrees and find good jobs to live under this present system. Some would call them "uppity niggas" who don't identify with those down there in the ghetto. They have found a way out through determination to rise above what the middle and upper class look down upon. (S. Ali, personal communication, June 11, 2020)

Gottfredson and Hirschi (1990) believed that criminals "lack self-control because they have been poorly trained as children, as a result of low parental investment in child rearing and 
poor monitoring and disciplining practices" (Lanier \& Henry, 2010, p. 197). Sal Ali agreed that it is important to warn and discipline children who exhibit criminal behavior because it could become a problem if they did not.

However, then there are parents who do everything that society requires one to do to be successful all around. I have seen and did time with white kids who lived good lives, did not have to rob, or steal nor use drugs, who were very vicious, sexual predators, and used weapons to kill and maim. They grew up without experiencing poverty, hunger or did not live in high crime areas. Even the early school shooters after Columbine High School. Most of the predominately white kids from a profile of family social standing that others in the ghetto dream of. Parents that do start out discipling children with multiple kids usually has one that falls off track and gets into things that the other siblings won't fall into. How would you label high school shooters different from the ones who steal money or property? Society changes the character of children and adults. Despite some of the best colleges and universities, many students develop a mind-set where they become educated in the field of stealing money to acquire high end living. Wall Street housing scandal 2008-2009. Are they not criminals? What happened to the indictments?

Look at the level of risk-taking and immediate gratification when a robber sees how he was able to push buttons on a computer to illegally transfer millions to an overseas bank account. Is this low self-esteem from not being properly reared at home by parents? He made it through high school, college and now has a corporate job that controls billions of dollars. He is in the position to buy or purchase Lear jets, yachts, property, and attorneys. What does he have to fear later in life? He or she is always where they want to be. Where is the self-control? Once the screen lights up and the millions transferred its time to light up the cigar. To hell with the consequences. I can afford big time lawyers. His parents did their best. Gave him everything. Is he a criminal? Yes, he committed stock exchange violations and stole from citizen investors who he swindled with cunning expertise learned in college. The school did not make him a criminal, nor did his parents. He chose this path well up in his age. Everything needed to make it through early life was there. We do not hear or read about such people often. Only about cats like me. (S. Ali, personal communication, June 11, 2020)

\subsection{Rational Choice Theory}

Another one of the major theories in modern criminology is Rational Choice Theory. Drawing heavily on the classical work of Beccaria (1738-1794) and Bentham (1748-1832) who posited that people are free-willed and make choices after a hedonistic analysis of the anticipated costs and benefits, Cornish and Clark (1986) and Herrnstein (1990) established this theory that hypothesized that criminals assess the likelihood of the consequences prior to their criminal behavior. This criminal decision-making is influenced by peoples' view of themselves, their upbringing, their experience, their hedonistic emotions (anger, frustration, immediate gratification) (Walters, 2015), and their social and demographic profile (e.g., sex, 
class, race).

The theory is based on several related principles including the idea that people are rational actors who make means/ends calculations to minimize pain and maximize pleasure expecting that the pleasure is an outcome of those calculations that consider the expectations of the certainty, swiftness and severity of punishment.

This rational calculating based on perceived costs and rewards can be seen in the following example from Sal's case:

You must be in a specific state of mind to commit a bank robbery. You need to be ready to be killed by anyone in line or by an armed cop in line waiting to cash his check or a citizen armed wanting to be able to be a hero to prevent you from taking bank money. It's a violent move with threats. No smoothness to robbing a bank, even with a note. The alarm (silent) can trigger a cop cruising by. The getaway can be deadly. A chase, then crash into someone. When you yell out to the people that it's a holdup, the blood flows. You don't know what's next. A hero or cop.

I had to leap over the counter and scoop up the dough myself. A dye pack with tear gas blew up on me once. Had to toss the bag out and was arrested days later after a co-defendant fingered me. That bomb dye smoke would never get me again. Embarrassed and a failure were the feelings. Ten years later, another arrest several weeks after a bank robbery. To hell with pickpocket shot playing or bank robbery. All have cost me a lifetime in prison. (S. Ali, personal communication, October 4, 2020)

Rational calculations about perceived risks and rewards are also hypothesized to explain increased offending specialization over time (Thomas, Loughran, \& Hamilton, 2020). While there may be versatility in offending over the life span, there is a tendency toward specialization as offenders' perceptions of their rewards from offending often increase as their skill in out carrying out a particular type of crime progresses over time:

As a criminal determined to carry out a robbery of a bank, I used skills developed over a long period of time. Even under the fear of death and after planning advanced escape techniques to avoid a chase by police or citizens, and even knowing the research information on robberies, I would have still carried out the robbery. There would have been the possibility of me changing my mind that could have frozen me in my tracks from moving forward. Seeing a cop enter the bank in uniform. If this had been a planned extensive use of energy to hit this bank specifically, I would have waited for the cop to clear out and leave. (S. Ali, personal communication, June 11, 2020)

\subsection{Life Perspective - Looking Back from Age 62}

With 27 years in prison and being 62 years old and having seen changes in society from 9-11 and now the new COVID 19 pandemic, Sal wonders about what work he would do when he is released. He would accept any work that would not degrade him. He wonders what has turned today's young people into some of the worse drug addicts and gang members he has 
seen since growing up.

Even white kids from rural areas are blending in with city youth to be a family member of street block gangs or hood block thugs that have no problem pulling the trigger. Who have I been doing time with for the past 27 years? Am I not in the position to help those who grew up like me that are wasting years away in confinement? There are others, unknown to the general public, with many years in prison, with similar histories who are waiting to help society; with these kids and young adults that need a different kind of approach in coming to grips with the wrong decisions they make - that leads to bad situations and in death more so today with this opioid situation that is in all parts of this country.

Some parts of the public do not care if many die from these things or feel that the cell block keys should be melted and never used to release the convicted. That may be so for some heinous, horrific crimes that some commit, but there is the other compassionate side to humans who want to build better people even those who have risen from the graves and dungeons to change and who will contribute. For years, I had the opportunity to meet with intelligent students who were on the right path of first making it all the way to college. Many minds and learned criminal skills come out of the schools beginning at the fifth and sixth grades. There is that low down rotten street life that has its attention. America the beautiful no doubt, but what parts do you call beautiful? The land, oceans, the millions of fun things to do. Then there are the ugly things we tend to turn away from. Poverty, violence, drug and alcohol addiction, inner city gangs, and other foolish shit.

What about those who teach students on these matters and the theories they have? Crime was here before me and you were born and will be here long after we are gone. Once, when I was young, my Pops and I were walking downtown Washington, DC and as we turned a corner an armored car truck had its door open while one guard stood up against the wall of a department store with a gun in his hand and the other guard was loading a few bags onto a dolly to bring into the store. So, Pops says to me, "don't even think about it." See, my Pops worked all his life. Never arrested nor been to prison. But he knew what was on my mind.

As a criminal I would have taken a shot at the chance to rob those guards even under the risk of killing or being killed. As someone wiser today, even if there was $\$ 2$ million in the bags the chaos that would have followed would have not been worth it even with $\$ 10$ million in the bags. To think about it is not a bad thing. To think then act, that is the real foolish thing. Doing time has its way of working on the once criminal mind. When my son was born, I was awaiting trial for my first bank robbery. $\mathrm{He}$ and his two sisters who both are both mothers, had to watch me from behind prison walls while growing up. I watched them grow up through prison visits and telephone calls. (S. Ali, personal communication, May 28, 2020)

Sal appeared before the Massachusetts State Parole Board this past September with two attorneys, along with 15 relatives and friends. This was his second appearance. The first was 
in 2014 when he had 21 years in. Then in April 2020 the parole board voted to deny his parole for another three years and keep him in confinement. They cited his criminal past, the fact that he was 35 years old at the time of his last crime and the fact that on a previous parole he had committed armed robberies.

Young people involved with the juvenile court system and students try to figure out why I had a mug shot when I was so young. It is clear, I kept going on and on until one judge said, "Life in Prison." My message has never changed while addressing young people. Do good things in life and good things will come to you. Do bad things to yourself and others while rejecting sound positive advice from your parents, friends, guidance counselor or teachers, clergy or from a friendly alley cat, then expect the roof to fall on you. Take a sniff of drugs today, tomorrow they may find you dead with a needle in your arm. Rob and steal from anyone, expect the law to rob you, too. Treat people like you wish to be treated. Look out for the poor who strive to educate themselves. Love your mother and father. You never know when they will leave you. (S. Ali, personal communication, May 28, 2020)

\section{Discussion and Implications}

It is clear that social learning theory, control theory and rational-choice theory all offer propositions that are applicable to understanding Sal Ali's entry into his life of crime and the continuance of that lifestyle up until he was finally given a life sentence. The analysis of this case study indicates that during his early childhood, Sal's mother, father, stepfather and other adults warned him of the consequences of his criminal involvements. The salience of these messages seem to be outweighed by the criminally reinforcing beliefs and attitudes he was learning from his peers. The frequency, duration, priority and intensity of Sal's associations as they changed over time and place help explain changes in his offending and non-offending pattern over time. As predicted by social learning theory (Akers \& Sellers, 2012; Akers, Sellers, \& Jennings, 2017), we found that across his criminal career Sal also learned the techniques of the crimes he committed from his peers. His offending trajectory became more serious as his associations with more seasoned offenders moved from his neighborhood to the Department of Youth Services and eventually to adult prisons and jails.

The lack of a steady father figure, a mother who was warm, but provided inconsistent supervision and discipline, likely contributed significantly to his life path. During his formative years, Sal experienced inconsistent childrearing because of varying parental styles and disciplinary practices among his biological parents and his stepfather. As a child, Sal had to navigate differences in practices and parenting styles, and he also experienced a number of disruptions and differences in his family structure and primary guardianship. Wong (2011) found a strong positive reciprocal relationship between family disruption, single-parent families and crime. Sal's mother undoubtedly was negatively affected by Sal's consistent trouble-making. In addition, a lack of adult supervision also seems to have been a marked feature of the times his mother was single and working. As suggested by self-control theory (Burt, Simons, \& Simons, 2006; Gottfredson \& Hirschi, 1990; Wright \& Beaver, 2005) this likely resulted in low self-control. The findings of this case study support previous research 
that indicates that the lack of self-control leads to a tendency not to consider broader or long-term consequences of your actions.

Sal's account of his offending career includes periods in which he reduced or refrained from offending and engaged more in conforming behavior. During these phases, he describes important attachments (social bonds) with adults (i.e., Father Carlton, Walter) and institutions (Woodside Boys Club, Sacred Heart home) that involved the positive reinforcement of conventional pursuits and mechanisms of both formal and informal social control. Sal's story seems to indicate that children who have low self-control can benefit when they achieve strong bonds with conforming people or within conventional institutions. We found less support for the notion that punishments or fear of punishment exerted external control in this case, as would be predicted by self-control (Hirschi, 1990) and rational choice theories (Cornish \& Clarke, 1986, Herrnstein, 1990). According to Sal, the physical punishments and warnings he received from his mother and stepfather had little influence on his decisions to engage in crime.

His experiences of formal punishments, first in the juvenile system and later in the adult system, seem to have had some effect on his perceptual calculations about the relative costs versus benefits associated with his crimes. Thomas, Thomas, Burgason and Wichinsky (2014) clearly demonstrate the significance of early contact with the criminal justice system as a predictor of the intellectual functioning of adult violent offenders. As other scholars (Jacobs, 2010; Sullivan, McGloin, Pratt, \& Piquero, 2006) have found, these experiences may help explain his specialization in committing serious robberies in order to maximize the benefits which he is so clearly able to articulate.

This case study of Sal Ali's life provides multiple theoretical insights into complex micro-level motivations and mechanisms involved in lifelong chronic offending. However, a primary limitation of the present study is the lack of attention to cultural and structural factors also present in this case: such as, racial prejudice, forced housing and school segregation, and structural racism. These factors existed alongside the micro level aspects of Sal's history. Sal's early life experience was especially influenced by the presence of school desegregation (Wolff, 2014) that Sal was a part of when he lived in the Boston area. We intentionally did not examine these macro issues as they were outside the focus of our theoretical analysis. Future studies investigating macro-level forces are needed to provide a more complete understanding of chronic criminal offending. Baumer, Horney, Felson and Lauritsen (2003), Hart and Walter (2013) and Smith, Frazee and Davison (2000) all explore the integration of micro and macro units of analysis.

The present in-depth analysis using the case study method uncovers many of the complexities in a chronic offending career that need to be attended to in micro level theories. The relative deprivation felt by Sal seems to have made the attitudes expressed by his peers toward offending more salient than forewarnings of punitive consequences often expressed by his parents, other adults and authority figures, including law enforcement and court officials. More particularly, the findings in this case support the learning aspects of acquiring the motivation and techniques for offending, but provides less support for the deterrent effect of 
criminal punishments proposed by rational choice theories. Future research with larger and more diverse samples are needed to confirm these findings. This case reinforces support for social policies that provide economic support for poor families and children without stigma, as these policies are likely to help reduce childhood relative deprivation and thus result in less crime and fewer children who begin an offending trajectory at a very young age, as was the case for Sal.

As suggested by Burt (2020) and her colleagues (Burt \& Simons, 2013: Burt, Sweeten \& Simons, 2014), this case study highlights the significance of social bonds and external controls during childhood, even in the absence of self-control. This is consistent with a number of previous studies (Hirschi, 1990; Nye, 1958; Reckless, 1967; Tittle, 1995) that underscore the importance of formal and informal social control. Sal's experiences indicate that juvenile prevention and rehabilitation strategies aimed at creating attachments to conventional people and institutions (i.e., sports, jobs) are likely to be more effective at reducing crime and changing offending trajectories than are strategies that bring young offenders together where they can learn how to improve their criminal techniques.

Moving forward, it would be especially valuable if more long-term incarcerated inmates could be found to offer their perspectives on how the social control, social learning and rational choice theories of crime applied to them. Analyzing the interactional process between personality, family structure, neighborhood, culture, race and the criminal justice system through the chronicling of their life histories would be a welcome addition to the traditional quantitative research typically based on statistical analysis of survey data.

What we found in Sal's case was a life of often conflicting values and changing motivations. While generalizations about criminal causation and motivations can only be suggested by our one case, a collection of such cases would be invaluable. Such a collection would offer an opportunity to increase the criminologist's understanding of the complex process of an emergent self-control (Burt, 2020) and the profound influence of situational perceptions (Jacobs, 2010) and emotions (Walters, 2015) that contribute to criminal behavior. And to further delineate crime preventative measures, this volume of cases could lead to a renewed analysis of the often dismissed early work of Hirschi (1969) who centralized the importance of attachment to conventional people, commitment to conventional endeavors and involvement in conventional activities.

\section{References}

Akers, R. L. (2000). Criminological theories: Introduction, evaluation, and application (3rd ed.). Los Angeles, CA: Roxbury Publishing Co.

Akers, R. L., \& Sellers, C. S. (2012). Criminological theories: Introduction, evaluation, and application (6th ed.). New York, NY: Oxford University Press.

Akers, R. L., Sellers, C. S. \& Jennings, W. G. (2017). Criminological theories; Introduction, evaluation, and application (7th ed.). New York, NY: Oxford University Press. 
Baumer, E., Horney, J., Felson, R., \& Lauritsen, J. L. (2003). Neighborhood disadvantage $\begin{array}{llll}\text { and the nature of violence. Criminology, 41(1), 39-72. } & \text {. }\end{array}$ https://doi.org/10.1111/j.1745-9125.2003.tb00981.x

Burgess, R., \& Akers, R. (1966). A differential association-reinforcement theory of criminal behavior. Social Problems, 14(2), 128-147. Doi: 10.2307/798612

Burt, C. H. (2020). Self-control and crime: Beyond Gottfredson and Hirschi's theory. Annual $\begin{array}{lllll}\text { Review of } & \text { Criminology, } & \text { 43-73. }\end{array}$ https://doi.org/10.1146/annurv-criminal-011419-041344

Burt, C. H., \& Simons, R. L. (2013). Self-control, thrill seeking, and crime. Criminal Justice and Behavior, 20(10), 1-23. Doi: 10.1177/0093854813485575

Burt, C. H., Simons, R. L., \& Simons, L. G. (2006). A longitudinal test of the effects of parenting and the stability of self-control: Negative evidence for the general theory of crime. Criminology, 44(2), 353-393. Doi: 10.1111/j.1745-9125.2006. 00052.x

Burt, C. H., Sweeten, G., \& Simons, R. L. (2014). Self-control through emerging adulthood: Instability, multidimensionality, and criminological significance. Criminology, 52(3), 450-487. https://doi.org/10.1111/1745-9125.12045

Cornish, D. B., \& Clarke, R. V. (1986). Crime as a rational choice. In The reasoning criminal. New York, NY: Springer-Verlag.

Dul, J., \& Hak, T. (2008). Case study methodology in business research. Abingdom, England: Routledge.

Ebneyamini, S., \& Moghadam, M. R. S. (2018). Toward developing a framework for conducting case study research. International Journal of Qualitative Methods, 17(1), 1-11. https://doi .org/10.1177/1609406918817954

Farmer, J. F., \& Dawson, J. (2017). American college students' shoplifting experience: A comparison of retrospective self-reports to micro-level criminological theory. International Journal of Criminal Justice Sciences, 12(1), 1-23. Doi: 10.5281/ZENODO .345700

Federal Bureau of Investigation [FBI]. (1976). Uniformed crime reports for the United States-1976. NCJRS Report \#135546. Washington, D.C.: United States Department of Justice.

Federal Bureau of Investigation [FBI]. (2018a). Crime in the United States 2018: Robbery. Washington, D.C., United States Department of Justice. Retrieved 5 January, 2021 from https:/ucr.fbi.gov/crime-in-the-u.s/2018/crime-in-the-u.s.-2018/topic-pages/robbery

Federal Bureau of Investigation [FBI]. (2018b). Crime in the United States 2018: Larceny-theft. Washington, D.C., United States Department of Justice. Retrieved 5 January, 2021

from https://ucr.fbi.gov/crime-in-the-u.s/2018/crime-in-the-u.s.-2018/topic-pages/larceny-thef 
$\mathrm{t}$

Felson, M. (2002). Crime and everyday life (3rd ed.). Thousand Oaks, CA: Sage Publishers.

Forrest, W., Hay, C., Widdowson, A. O., \& Rocque, M. (2019). Development of impulsivity and risk-seeking: Implications for the dimensionality and stability of self-control. Criminology, 57(3), 512-542. https://doi.org/10.1111/1745-9125.12214

Glaeser, E. (2012). Triumph of the city: How our greatest invention makes us richer, smarter, greener, healthier, and happier. Economic Geography, 88(1), 97-100. https://doi.org/10.1111/j.1944-8287.2011.01134.x

Gottfredson, M., \& Hirschi, T. (1990). A general theory of crime. Palo Alto, CA: Stanford University Press.

Grasmick, H., Tittle, C., Bursik, R., \& Arneklev, B. (1993). Testing the core empirical implications of Gottfredson and Hirschi's general theory of crime. Journal of Research in Crime and Delinquency, 30(1), 5-29. https://doi.org/10.1177/0022427893030001002

Handfield, R. B., \& Melnyk, S. A. (1998). The scientific theory-building process: A primer using the case of TQM. Journal of Operations Management, 16(4), 321-339. https://doi.org/10.1016/S0272-6963(98)00017-5

Hart, T. C., \& Waller, J. (2013). Neighborhood boundaries and structural determinants of social disorganization: Examining the validity of commonly used measures. Western Criminology Review, 14(3), 16-33.

Herrnstein, R. J. (1990). Rational choice theory: Necessary but not sufficient. American Psychologist, 45(3), 356-367. https://doi.org/10.1037/0003-066X.45.3.356

Hirschi, T. (1969). Causes of delinquency. Berkley, CA: University of California Press.

Holt, T., Bossler, A., \& Seigfried-Spellar, K. (2015). Cybercrime and digital forensics: An introduction. Oxford, England: Routledge.

Hyett, N., Kenny, A., \& Dickson-Swift, V. (2014). Methodology or method? A critical review of qualitative case study reports. International Journal of Qualitative Studies on Health and Well-Being, 9(1), 1-12. https://doi.org/10.3402/qhw. v9.23606

Jacobs, B. A. (2010). Serendipity in robbery target selection. The British Journal of Criminology, 50(3), 514-529. Retrieved 5 January, 2021 from https://www.jstor.org/stable/43612867

Johansson, R. (2003). Case study methodology: Methodologies in housing research. Stockholm: Royal Institute of Technology in cooperation with the International Association of People-Environment Studies.

Jones, S. (2017). Criminology. Oxford, UK: Oxford University Press.

Keohane, J. (2011). The lost art of pickpocketing: The venerable crime has all but disappeared in the United States. What happened and should we miss it? Slate, 2, 1-12. 
Retrieved January, 2021 from https://slate.com/culture/2011/02/the-lost-art-of-pickpocketing-why-has-the-crime-beco me-so-rare-n-the-United-States

Lanier, M. M., \& Henry, S. (2010). Essential criminology (3rd ed.). Boulder, CO: Westview Press.

Nee, C., van Gelder, J., Otte, M., Vernham, Z., \& Meenaghan. A. (2019). Learning on the job: Studying expertise in residential burglars using virtual environments. Criminology, 57(3), 481-511. https://doi.org/10.1111/1745-9125.12210

Nye, I. (1958). Family relationships and delinquent behavior. New York, NY: John Wiley.

Reckless, W. (1967). The crime problem (4th ed.). New York, NY: Appleton-Century-Crofts.

Reilly, B., Rickman, N., \& Witt, R. (2012). Robbing banks: Crime does pay - but not very much. Significance, 9(3), 17-21. https://doi.org/10.111/j.1740-9313.2012. 000570.x

Schramm, W. (1971). Notes on case studies of instructional media points. Washington, DC: Academy for Educational Development.

Smith, W. R., Frazee, S. G., \& Davison, E. L. (2000). Furthering the integration of routine activity and social disorganization theories: Small units of analysis and the study of street robbery as a diffusion process. Criminology, 38(2), 489-523. https://doi.org/10.1111/j.1745-9125. 2000.tb00897.x

Stake, R. E. (1995). The art of case study. Thousand Oaks, CA: Sage.

Sullivan, C. J., McGloin, J. M., Pratt, T. C., \& Piquero, A. C. (2006). Rethinking the "norm" of offender generality: Investigating specialization in the short-term. Criminology, 44(1), 199-233. https://doi.org/10.1111/j.1745-9125.2006. 00047.x

Sutherland, E. (1939). Principles of criminology (3rd ed.). Philadelphia, PA: Lippincott.

Sutherland, E., \& Cressey, D. R. (1950). Principles of criminology (5th ed.). Chicago, IL: Lippincott.

Tellis, W. M. (1997). Introduction to case study. The Qualitative Report, 3(2), 1-14.

Thomas, J. M., Thomas, S. A., Burgason, K. A., \& Wichinsky, L. C. (2014). Early contact with the criminal justice system and intellectual functioning as risk factors for violent and chronic adult offending. Western Criminology Review, 15(1), 34-50. Retrieved 5 January, 2021 from http://wcr.sonoma.edu/v15n1/Thomas.pdf

Thomas, K. J., Loughran, T. A., \& Hamilton, B. C. (2020). Perceived arrest risk, psychic rewards, and offense specialization: A partial test of rational choice theory. Criminology, 58(3), 485-509. https://doi.org/10.1111/1745-9125.12243

Tittle, C. (1975). Deterrents or labeling? Social Forces, 53(3), 399-410. https://doi.org/10.1093/sf/53.3.399 
Topalli, V., Jacques, S., \& Wright, R. (2015). "It takes skills to take a car": Perceptual and procedural expertise in carjacking. Aggression and Violent Behavior, 20(1), 19-25. https://doi.org/10.1016/j.avb.2014.12.001

Triplett, R. (2015). Crime, social learning of. In G. Ritzer (Ed.), The Blackwell Encyclopedia of Sociology (pp. 1-3). Hoboken, NJ: John Wiley \& Sons. Doi: 10.1002/9781405165518. wbeosc 157.pub2

Vieraitis, L., Copes, H., Powell, Z., \& Pike, A. (2015). A little information goes a long way: Expertise and identity theft. Aggression and Violent Behavior, 20(1), 10-18. https://doi.org/10.1016/j.avb.2014.12.008

Walters, G. D. (2015). The decision to commit crime: Rational or nonrational? Criminology, Criminal Justice Law, and Society, 16(3), 1-18. https://doi.org/10.21202/1993-047X.10.2016.3.252-270

Willis, K. (2006). Armed robbery: Who commits it and why. Trends and Issues in Crime and Criminal Justice, 328, 1-6.

Wolff, J. (2014). A timeline of Boston school desegregation, 1961-1985: with emphasis on 1964-1976. Boston, MA: Civil Rights and Restorative Justice Project, Northeastern University School of Law. Retrieved 5 January, 2021 from https://www.racialequitytools.org /resourcefiles/Boston \%20Timeline.pdf

Wong, S. K. (2011). Reciprocal effects of family disruption and crime: A panel study of Canadian municipalities. Western Criminology Review, 12(1), 43-63.

Wright, J. P., \& Beaver, K. M. (2005). Do parents matter in creating self-control in their children? A genetically informed test of Gottfredson and Hirschi's theory of low $\begin{array}{lll}\text { self-control. Criminology, } & \text { 43(4), }\end{array}$ https://doi.org/10.1111/j.1745-9125.2005.00036.x

Yazan, B. (2015). Three approaches to case study methods in education: Yin, Merriam, and Stake. The Qualitative Report, 20, 134-152.

Yin, R. K. (2003). Case study research: Design and methods. London: Sage.

\section{Copyright Disclaimer}

Copyright for this article is retained by the author(s), with first publication rights granted to the journal.

This is an open-access article distributed under the terms and conditions of the Creative Commons Attribution license (http://creativecommons.org/licenses/by/3.0/). 